\title{
Methylobacterium isbiliense sp. nov., isolated from the drinking water system of Sevilla, Spain
}

\author{
Virginia Gallego, Maria Teresa García and Antonio Ventosa \\ Department of Microbiology and Parasitology, Faculty of Pharmacy, University of Sevilla, 41012 \\ Sevilla, Spain
}

Correspondence

Antonio Ventosa

ventosa@us.es

\begin{abstract}
Three pink-pigmented facultatively methylotrophic bacteria were isolated from drinking water. These strains (designated AR24 ${ }^{\top}$, AR25 and GR32) have been characterized on the basis of phenotypic traits, 16S rRNA gene sequence analysis and DNA-DNA hybridization. According to the results of these analyses, the three strains belong to the genus Methylobacterium. Analysis of $16 \mathrm{~S}$ rRNA gene sequences revealed that the three isolates constituted a single phylogenetic group. The level of 16S rRNA gene sequence similarities with respect to the type strains of the genus Methylobacterium were less than $96.5 \%$, except for the type strain of Methylobacterium nodulans (98.1\%). The $\mathrm{G}+\mathrm{C}$ content of their DNA ranged from $69 \cdot 0$ to $69 \cdot 7 \mathrm{~mol} \%$. DNA-DNA hybridization values confirmed that they constitute a novel species for which we propose the name Methylobacterium isbiliense sp. nov. The type strain is AR24 $\left(=\right.$ CECT $7068^{\top}=$ CCM $\left.7304^{\top}\right)$.
\end{abstract}

Members of the genus Methylobacterium are ubiquitous in nature and are thus found in a variety of habitats (Green \& Bousfield, 1981, 1983) including soil, dust, freshwater, tap water systems, lake sediments, leaf surfaces and root nodules, rice grains, air, hospital environments, and as contaminants in various products and processes. Species of Methylobacterium have been reported to exhibit resistance to chlorination (Hiraishi et al., 1995). Moreover, some Methylobacterium species are clinically opportunistic bacteria and have been found to cause urinary tract infections (Chen-Hsiang et al., 2004).

Species of this genus belong to the $\alpha-2$ subclass of the Proteobacteria and are strictly aerobic, Gram-negative, rod-shaped, pink-pigmented, facultatively methylotrophic (PPFM) bacteria, which can grow on $\mathrm{C}_{1}$ compounds such as formate, formaldehyde and methanol as sole source of carbon and energy, as well as on a wide range of multicarbon growth substrates (Green, 2000). At the time of writing the genus Methylobacterium consists of 19 species (Patt et al., 1976; Green \& Bousfield, 1983; Bousfield \& Green, 1985; Green et al., 1988; Urakami et al., 1993; Wood et al., 1998; Doronina et al., 2000; McDonald et al., 2001; Doronina et al., 2002; Van Aken et al., 2004; Jourand et al., 2004; Gallego et al., 2005a, b), the type species being Methylobacterium organophilum (Patt et al., 1976).

Published online ahead of print on 13 October 2005 as DOI 10.1099/ ijs.0.63773-0.

The GenBank/EMBL/DDBJ accession numbers for the 16S rRNA gene sequence of strains GR32, AR25 and AR24 ${ }^{\top}$ are AJ888241, AJ888240 and AJ888239, respectively.
Our previous studies focused on the determination of bacterial diversity found in drinking water, leading to the description of three new species of the genus Methylobacterium: Methylobacterium aquaticum, Methylobacterium hispanicum (Gallego et al., 2005a) and Methylobacterium variabile (Gallego et al., 2005b). The massive presence of these pink-pigmented bacteria in our first sampling campaign led us to carry out a second campaign for a more complete study of the incidence of these micro-organisms in potable tap water. In this paper we describe the features of three new pink-pigmented isolates that constitute a new species of the genus Methylobacterium for which we propose the name Methylobacterium isbiliense sp. nov.

A total of 25 litres of drinking water samples was collected from four different points in the water distribution system of Sevilla (Spain). Samples were concentrated by using a tangential flow filtration system (Filtron) and plated on Plate Count Agar (PCA-Difco) and R2A agar medium (Difco). Plates were incubated at $28^{\circ} \mathrm{C}$ for 7 days and pinkpigmented colonies were plated to obtain pure cultures. Chromosomal DNA of these isolates was extracted and the $16 \mathrm{~S}$ rRNA gene of all isolates was amplified by using two universal primers (Eubak5, 5' -AGAGTTTGATC(AC)TGGCT-3', and C1392R, 5'-CCACGGGCGGTGTGTAC-3'). Nearly full-length $16 \mathrm{~S}$ rRNA gene sequences were obtained and phylogenetic analyses were performed by using the ARB software package (Ludwig \& Strunk, 1996). Sequencing was performed by NBT-Newbiotechnic (Sevilla, Spain) using an automated DNA sequencer model 3100 (Applied Biosystems). Phylogenetic trees were inferred by using three tree-making algorithms: maximum-parsimony, neighbourjoining and maximum-likelihood methods. Strains AR24 ${ }^{\mathrm{T}}$, 
AR25 and GR32 grouped together, forming a separate phylogenetic branch in the three phylogenetic trees, sharing $100 \%$ sequence similarity (Fig. 1). Their closest relative was M. nodulans, showing $98 \cdot 1 \%$ sequence similarity, whereas the similarity values with respect to other type species belonging to the genus Methylobacterium were lower than $96.5 \%$. Although the $16 \mathrm{~S}$ rRNA gene sequence similarity with respect to $M$. nodulans was higher than $97 \%$, the colonies of this species are not pink-pigmented when they grow on MMS agar medium (Green, 2000), and this made us to continue with the characterization of these three strains.

The three pink-pigmented cultures were isolated from two different points in the drinking water distribution system, but all three were isolated from R2A agar isolation medium. They were phenotypically characterized by using the methods described by Doronina et al. (1998). Cell morphology, Gram staining, motility, and growth at different $\mathrm{pH}$ values, temperatures and concentrations of $\mathrm{NaCl}(0-4 \%)$ were determined on liquid and solid R2A medium. Nutritional features were determined as described previously (Gallego et al., 2005b) by using Biolog Microplates.

Strains AR24 ${ }^{\mathrm{T}}$, AR25 and GR32 were Gram-negative rods, motile and strictly aerobic, measuring $1 \cdot 0-1 \cdot 3 \mu \mathrm{m}$ wide by $2 \cdot 0-5 \cdot 0 \mu \mathrm{m}$ long in $24 \mathrm{~h}, \mathrm{R} 2 \mathrm{~A}$ liquid medium cultures, incubated at $28^{\circ} \mathrm{C}$. Colonies of these strains were circular, regular in shape and pink-pigmented. The three strains could grow from $\mathrm{pH} 4$ to $\mathrm{pH} 10$, and from 20 to $37^{\circ} \mathrm{C}$; no growth occurred in the presence of $1 \% \mathrm{NaCl}$. Urease was produced, the methyl-red and Voges-Proskauer tests were negative and $\mathrm{H}_{2} \mathrm{~S}$ was not produced, as for all species of the genus Methylobacterium (Green, 2000).

Chromosomal DNA for DNA-DNA hybridization and $\mathrm{G}+\mathrm{C}$ content determination was isolated and purified according to the methods described by Wilson (1987) and Marmur (1961), as partially modified by Hood et al. (1987). The DNA G + C content was determined from the midpoint value $\left(\mathrm{T}_{\mathrm{m}}\right)$ of the thermal denaturation profile (Marmur \& Doty, 1962) in $0 \cdot 1 \times$ SSC buffer and was obtained with a Perkin-Elmer Lambda 20 spectrophotometer at $260 \mathrm{~nm}$ programmed for temperature increases of $1 \cdot 0{ }^{\circ} \mathrm{C} \min ^{-1}$. The $\mathrm{G}+\mathrm{C}$ content was calculated from this temperature by using the equation of Owen \& Hill (1979). DNA was labelled by the multiprime system with a commercial kit (Prime-a-Gene Labelling System; Promega). The labelled DNA was denatured prior to hybridization by heating at $100^{\circ} \mathrm{C}$ for $5 \mathrm{~min}$ and then placed on ice. DNADNA hybridization studies were performed by the competition procedure of the membrane method described by

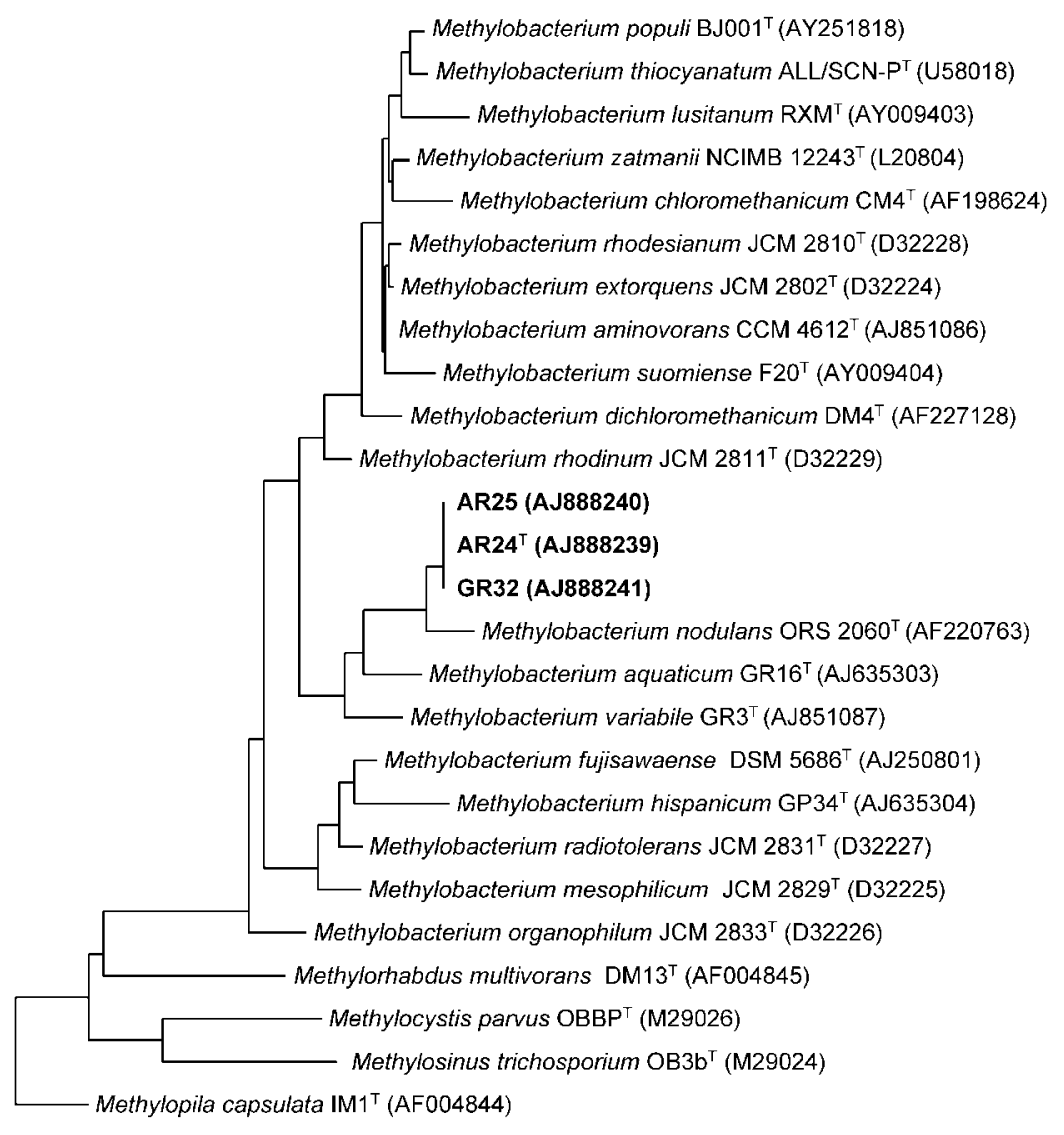

Fig. 1. Phylogenetic tree based on $16 \mathrm{~S}$ rRNA gene sequence comparison showing the position of the three strains (AR24 ${ }^{\top}, A R 25$ and GR32) and other related species of the genus Methylobacterium. The tree was obtained using the maximum-parsimony method. GenBank accession numbers are included in parentheses. Bar, $2 \%$ sequence divergence. 
Johnson (1994), as described in detail by Mormile et al. (1999). The hybridization temperature was $61^{\circ} \mathrm{C}$, which is within the limit of validity for the filter method (De Ley \& Tijtgat, 1970) and the percentage hybridization was calculated according to Johnson (1994). The experiments were carried out in triplicate.

The $\mathrm{G}+\mathrm{C}$ content of the DNAs of the three strains ranged from $69 \cdot 0$ to $69 \cdot 7 \mathrm{~mol} \%$; the $\mathrm{G}+\mathrm{C}$ of strain $\mathrm{AR} 24^{\mathrm{T}}$ was $69 \mathrm{~mol} \%$. These values are within the range of $\mathrm{G}+\mathrm{C}$ content described for the genus Methylobacterium (Hood et al., 1987; Urakami et al., 1993). The percentage DNA-DNA hybridization between the type strain AR24 ${ }^{\mathrm{T}}$ and strain GR32 was $99 \%$, confirming the close relationship between these strains (Fig. 1). On the other hand, the percentage hybridization between closely related Methylobacterium species and strain $\mathrm{AR} 24^{\mathrm{T}}$ ranged between 14 and $37 \%$ for Methylobacterium aquaticum DSM $16371^{\mathrm{T}}$ and Methylobacterium nodulans LMG $21967^{\mathrm{T}}$, respectively. On the basis of these results, and taking into consideration the criteria recommended by Wayne et al. (1987), these strains constitute a new taxonomic unit.

The DNA-DNA hybridization results, the phylogenetic data and several phenotypic features allowed strains AR24 ${ }^{\mathrm{T}}$, AR25 and GR32 to be differentiated from other members of the genus Methylobacterium. A novel species,
Methylobacterium isbiliense sp. nov., is therefore proposed to accommodate the three strains. Table 1 shows some phenotypic features that differentiate this species from other related species of the genus Methylobacterium.

\section{Description of Methylobacterium isbiliense sp. nov.}

Methylobacterium isbiliense (is.bil.i.en'se. L. neut. adj. isbiliense from Isbilia, the old name for the city of Sevilla, Spain, from where the bacterium was isolated).

Gram-negative rods, $1-1 \cdot 3 \times 2-5 \mu \mathrm{m}$, occurring singly or forming aggregates. Cells are motile, non-spore-forming and strictly aerobic. Colonies are pink, circular, regular in shape and $1-2 \mathrm{~mm}$ in diameter after 7 days at $28^{\circ} \mathrm{C}$ on R2A medium. Slow-growing (no growth is obtained before 3-4 days in R2A solid medium) and does not grow in the presence of $1.0 \% \mathrm{NaCl}$ or higher. Growth occurs at $20-37^{\circ} \mathrm{C}$ (optimal temperature $28^{\circ} \mathrm{C}$ ) and at $\mathrm{pH} 4 \cdot 0-10 \cdot 0$ (optimal $\mathrm{pH}$ between $6 \cdot 0$ and $7 \cdot 0$ ). Oxidase and catalase activities are weakly positive. Urease is positive. Indole production, methyl red and Voges-Proskauer are negative. Starch is hydrolysed. Gelatin, Tween 80 , caseine and DNA are not hydrolysed. Hydrogen sulfide is not produced. Simmons' citrate test is positive. Nitrate is not reduced. Acid is not produced from D-glucose, D-galactose, D-mannose,

Table 1. Differential phenotypic characteristics of Methylobacterium isbiliense and other related species of the genus Methylobacterium

Symbols: ND, Not determined; $\mathrm{W}$, weak; V, variable; +, positive; -, negative. Bacteria are identified as: 1, Methylobacterium isbiliense AR24 $4^{\mathrm{T}}$; 2, Methylobacterium nodulans LMG $21967^{\mathrm{T}}$ (Jourand et al., 2004); 3, Methylobacterium variabile GR3 ${ }^{\mathrm{T}}$ (Gallego et al., 2005b); 4, Methylobacterium hispanicum CCM $7219^{\mathrm{T}}$ (Gallego et al., 2005a); 5, Methylobacterium aquaticum CCM $7218^{\mathrm{T}}$ (Gallego et al., 2005a); 6, Methylobacterium aminovorans JCM 8240 ${ }^{\mathrm{T}}$ (Urakami et al., 1993); 7, Methylobacterium suomiense NCIMB 13778 ${ }^{\mathrm{T}}$ (Doronina et al., 2002); 8, Methylobacterium lusitanum NCIMB $13779^{\mathrm{T}}$ (Doronina et al., 2002); 9, Methylobacterium thiocyanatum NCIMB $13651^{\mathrm{T}}$ (Wood et al., 1998); 10, Methylobacterium chloromethanicum NCIMB $13688^{\mathrm{T}}$ (McDonald et al., 2001); 11, Methylobacterium populi NCIMB $13946^{\mathrm{T}}$ (Van Aken et al., 2004).

\begin{tabular}{|c|c|c|c|c|c|c|c|c|c|c|c|}
\hline Characteristic & 1 & 2 & 3 & 4 & 5 & 6 & 7 & 8 & 9 & 10 & 11 \\
\hline \multicolumn{12}{|l|}{ Cells occur: } \\
\hline Singly & + & + & + & + & + & + & + & + & $\mathrm{ND}$ & ND & + \\
\hline Aggregates/rosettes & + & - & + & - & + & - & - & - & $\mathrm{ND}$ & $\mathrm{ND}$ & + \\
\hline Cell length $(\mu \mathrm{m})$ & $2-5$ & $1-1 \cdot 5$ & $2-6$ & $2-2 \cdot 5$ & $4 \cdot 5-8$ & $1 \cdot 5-4$ & $1 \cdot 2-2 \cdot 5$ & $1 \cdot 7-2$ & 2 & $2 \cdot 5-3 \cdot 5$ & $1-10$ \\
\hline $\begin{array}{l}\text { Diameter of colonies } \\
(\mathrm{mm})\end{array}$ & $1-2$ & $0 \cdot 5-1$ & $2-7$ & $1-2$ & $1-2$ & $1-3$ & $0 \cdot 5-1$ & 1 & $1 \cdot 5$ & $\mathrm{ND}$ & $0 \cdot 1-0 \cdot 2$ \\
\hline Oxidase & $+(\mathrm{w})$ & $+(\mathrm{w})$ & - & $+(\mathrm{w})$ & - & + & $+(\mathrm{w})$ & $+(\mathrm{w})$ & $\mathrm{v}$ & $\mathrm{ND}$ & + \\
\hline \multicolumn{12}{|l|}{ Growth on: } \\
\hline Citrate & + & + & + & + & + & - & - & - & + & + & - \\
\hline
\end{tabular}


maltose, D-arabinose and fructose. Methanol, formate and formaldehyde are utilized as sole carbon sources. Ammonium sulfate, aspartate and glutamate are utilized as sole nitrogen sources. The following compounds are utilized as sole carbon and energy sources (Biolog): acetic acid, $\gamma$-hydroxybutyric acid, $\alpha$-ketoglutaric acid, L-lactic acid, L-malic acid, monomethyl succinate, propionic acid, pyruvic acid, succinamic acid, succinic acid and L-glutamic acid. The following compounds are not utilized as sole carbon and energy sources (Biolog): $\alpha-$ cyclodextrin, $\beta$-cyclodextrin, dextrin, glycogen, inulin, mannan, Tween 40, Tween 80, $\mathrm{N}$-acetyl-D-glucosamine, $\mathrm{N}$ acetyl-D-mannosamine, amygdalin, L-arabinose, D-arabitol, arbutin, cellobiose, D-fructose, L-fucose, D-galactose, Dgalacturonic acid, gentibiose, D-gluconic acid, $\alpha$-D-glucose, $m$-inositol, $\alpha$-D-lactose, lactulose, maltose, maltotriose, $\mathrm{D}$ mannitol, D-mannose, D-melezitose, D-melobiose, $\alpha$-methylD-galactoside, $\beta$-methyl-D-galactoside, 3 -methylglucose, $\alpha$-methyl-D-glucoside, $\beta$-methyl-D-glucoside, $\alpha$-methyl-Dmannoside, palatinose, D-psicose, D-raffinose, L-rhamnose, D-ribose, salicin, sedoheptulosan, D-sorbitol, stachyose, sucrose, D-tagatose, D-trehalose, turanose, xylitol, Dxylose, $\alpha$-hydroxybutyric acid, $\beta$-hydroxybutyric, $p$ hydroxyphenylacetic acid, $\alpha$-ketovaleric acid, lactamide, D-lactic acid methyl ester, D-malic acid, methylpyruvate, $\mathrm{N}$-acetyl-L-glutamic acid, alaninamide, D-alanine, L-alanine, L-alanyl-glycine, L-asparagine, glycyl-L-glutamic acid, Lpyroglutamic acid, L-serine, putrescine, 2,3-butanediol, glycerol, adenosine, 2 '-deoxyadenosine, inosine, thymidine, uridine, adenosine- $5^{\prime}$-monophosphate, thymidine- $5^{\prime}$ monophosphate, uridine- $5^{\prime}$-monophosphate, fructose 6phosphate, glucose 1-phosphate, glucose 6-phosphate and DL- $\alpha$-glycerol phosphate. Isolated from drinking water. The DNA G $+\mathrm{C}$ content is $69 \cdot 0-69 \cdot 7 \mathrm{~mol} \%$. The type strain is strain AR24 $4^{\mathrm{T}}\left(=\right.$ CECT $\left.7068^{\mathrm{T}}=\mathrm{CCM} 7304^{\mathrm{T}}\right)$. The DNA $\mathrm{G}+\mathrm{C}$ content of the type strain is $69 \cdot 0 \mathrm{~mol} \%$. The accession number for the $16 \mathrm{~S}$ rRNA sequence of strain $\mathrm{AR} 24^{\mathrm{T}}$ is AJ888239.

\section{Acknowledgements}

V. Gallego was supported by a fellowship from the Spanish Ministerio de Educación y Ciencia. This work was supported by grants from the Quality of Life and Management of Living Resources Programme of the European Commission (QLK3-CT-2002-01972), Spanish Ministerio de Educación y Ciencia (BMC2003-01344) and from the Junta de Andalucía.

\section{References}

Bousfield, I. J. \& Green, P. N. (1985). Reclassification of bacteria of the genus Protomonas Urakami and Komagata 1984 in the genus Methylobacterium (Patt, Cole, and Hanson) emend. Green and Bousfield 1983. Int J Syst Bacteriol 35, 209.

Chen-Hsiang, L., Ya-Fen, T. \& Jien-Wei, L. (2004). Underdiagnosis of urinary tract infection caused by Methylobacterium species with current standard processing of urine culture and its clinical implications. J Med Microbiol 53, 755-759.
De Ley, J. \& Tijtgat, R. (1970). Evaluation of membrane filter methods for DNA-DNA hybridization. Antonie van Leeuwenhoek 36, 461-474.

Doronina, N. V., Trotsenko, Y. A., Krausova, V. I., Boulygina, E. S. \& Tourova, T. P. (1998). Methylopila capsulata gen. nov., sp. nov., a novel non-pigmented aerobic facultatively methylotrophic bacterium. Int J Syst Bacteriol 48, 1313-1321.

Doronina, N. V., Trotsenko, Y. A., Tourova, T. P., Kuznetsov, B. B. \& Leisinger, T. (2000). Methylopila helvetica sp. nov. and Methylobacterium dichloromethanicum sp. nov., novel aerobic facultatively methylotrophic bacteria utilizing dichloromethane. Syst Appl Microbiol 23, 210-218.

Doronina, N. V., Trotsenko, Y. A., Kuznetsov, B. B., Tourova, T. P. \& Salkinoja-Salonen, M. S. (2002). Methylobacterium suomiense sp. nov. and Methylobacterium lusitanum sp. nov., aerobic, pinkpigmented, facultatively methylotrophic bacteria. Int J Syst Evol Microbiol 52, 773-776.

Gallego, V., Garcia, M. T. \& Ventosa, A. (2005a). Methylobacterium hispanicum sp. nov. and Methylobacterium aquaticum sp. nov., isolated from drinking water. Int J Syst Evol Microbiol 55, 281-287.

Gallego, V., Garcia, M. T. \& Ventosa, A. (2005b). Methylobacterium variabile sp. nov., a methylotrophic bacterium isolated from an aquatic environment. Int J Syst Evol Microbiol 55, 1429-1433.

Green, P. N. (2000). The genus Methylobacterium. In the Prokaryotes, Online Edn, http://141.150.157.117:8080/prokPUB/index. htm. Edited by M. Dworkin. New York: Springer.

Green, P. N. \& Bousfield, I. J. (1981). The taxonomy of pinkpigmented facultatively methylotrophic bacteria. In Microbial Growth on C1-Compounds, pp. 285-293. Edited by H. Dalton. London: Heyden \& Son Ltd.

Green, P. N. \& Bousfield, I. J. (1983). Emendation of Methylobacterium Patt, Cole, and Hanson 1976; Methylobacterium rhodinum (Heumann 1962) comb. nov. corrig.; Methylobacterium radiotolerans (Ito \& Iizuka 1971) comb. nov., corrig.; and Methylobacterium mesophilicum (Austin \& Goodfellow 1979) comb. nov. Int J Syst Bacteriol 33, 875-877.

Green, P. N., Bousfield, I. J. \& Hood, D. (1988). Three new Methylobacterium species: M. rhodesianum sp. nov., M. zatmanii sp. nov., and M. fujisawaense sp. nov. Int J Syst Bacteriol 38, 124-127. Hiraishi, A., Furuhata, K., Matsumoto, A., Koike, K. A., Fukuyama, M. \& Tabuchi, K. (1995). Phenotypic and genetic diversity of chlorineresistant Methylobacterium strains isolated from various environments. Appl Environ Microbiol 61, 2099-2107.

Hood, D. W., Dow, C. S. \& Green, P. N. (1987). DNA:DNA hybridization studies on the pink-pigmented facultative methylotrophs. J Gen Microbiol 38, 709-720.

Johnson, J. L. (1994). Similarity analysis of DNAs. In Methods for General and Molecular Bacteriology, pp. 655-681. Edited by P. Gerhardt, R. G. E. Murray, W. A. Wood \& N. R. Krieg. Washington, DC: American Society for Microbiology.

Jourand, P., Giraud, E., Bena, G., Sy, A., Willens, A., Gillis, M., Dreyfus, B. \& Lajudie, P. (2004). Methylobacterium nodulans sp. nov., for a group of aerobic, facultatively methylotrophic, legume root-nodule-forming and nitrogen-fixing bacteria. Int J Syst Evol Microbiol 54, 2269-2273.

Ludwig, W. \& Strunk, O. (1996). ARB - a software environment for sequence data (http://www.mikro.biologie.tu-muenchen.de).

Marmur, J. (1961). A procedure for the isolation of deoxyribonucleic acid from micro-organisms. J Mol Biol 3, 208-218.

Marmur, J. \& Doty, P. (1962). Determination of the base composition of deoxyribonucleic acid from its thermal denaturation temperature. J Mol Biol 5, 109-118. 
McDonald, I. R., Doronina, N. V., Trotsenko, Y. A., McAnulla, C. \& Murrell, J. C. (2001). Hyphomicrobium chloromethanicum sp. nov. and Methylobacterium chloromethanicum sp. nov., chloromethaneutilizing bacteria isolated from a polluted environment. Int J Syst Evol Microbiol 51, 119-122.

Mormile, M. R., Romine, M. F., García, M. T., Ventosa, A., Bailey, T. J. \& Peyton, B. M. (1999). Halomonas campisalis sp. nov., a denitrifying, moderately haloalkaliphilic bacterium. Syst Appl Microbiol 22, 551-558.

Owen, R. J. \& Hill, L. R. (1979). The estimation of base compositions, base pairing and genome size of bacterial deoxyribonucleic acids. In Identification Methods for Microbiologists, 2nd edn, pp. 217-296. Edited by F. A. Skinner \& D. W. Lovelock. London: Academic Press.

Patt, T. E., Cole, G. C. \& Hanson, R. S. (1976). Methylobacterium, a new genus of facultatively methylotrophic bacteria. Int J Syst Bacteriol 26, 226-229.

Urakami, T., Araki, H., Suzuki, K.-I. \& Komagata, K. (1993). Further studies of the genus Methylobacterium and description of Methylobacterium aminovorans sp. nov. Int J Syst Bacteriol 43, 504-513.
Van Aken, B., Peres, C. M., Lafferty-Doty, S., Yoon, J. M. \& Schnoor, J. L. (2004). Methylobacterium populi sp. nov., a novel aerobic, pinkpigmented, facultatively methylotrophic, methane-utilizing bacterium isolated from poplar trees (Populus deltoides $\times$ nigra DN34). Int J Syst Evol Microbiol 54, 1191-1196.

Wayne, L. G., Brenner, D. J., Colwell, R. R. \& 9 other authors (1987). International Committee on Systematic Bacteriology. Report of the ad hoc committee on reconciliation of approaches to bacterial systematics. Int J Syst Bacteriol 37, 463-464.

Wilson, K. (1987). Preparation of genomic DNA from bacteria. In Current Protocols in Molecular Biology, pp. 2.4.1-2.4.2. Edited by F. M. Ausubel, R. Brent, R. E. Kingston, D. D. Moore, J. G. Seidman, J. A. Smith \& K. Struhl. New York: Wiley.

Wood, A. P., Kelly, D. P., McDonald, I. R., Jordan, S. L., Morgan, T. D., Khan, S., Murrell, J. C. \& Borodina, E. (1998). A novel pinkpigmented facultative methylotroph, Methylobacterium thiocyanatum sp. nov., capable of growth on thiocyanate or cyanate as sole nitrogen sources. Arch Microbiol 169, 148-158. 